\title{
LAST GREAT ICE-AGE FLOOD DOWN GRAND COULEE
}

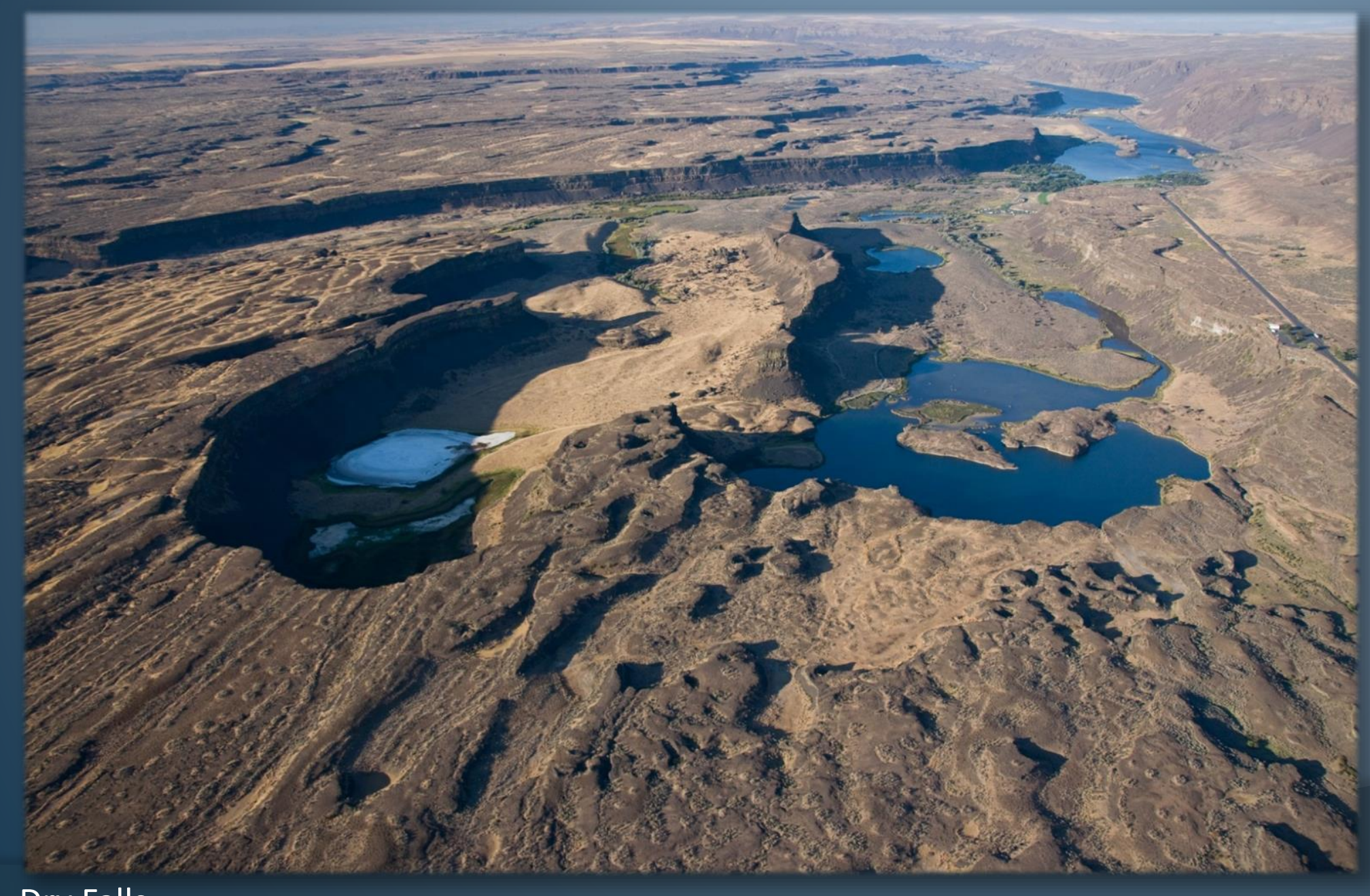

Bruce Bjornstad

Eugene Kiver 


\section{Premise}

○ The last flood down Grand Coulee occurred several hundred years after the last Lake Missoula flood when an expansion flood bar (debris dam) at the mouth of the upper Grand Coulee was suddenly breached, releasing a 300$\mathrm{ft}$ wall of floodwater into the lower Grand Coulee and beyond. 


\section{Grand Coulee}

- Created by Ice Age floods as recently as 15,000 years ago.

( 50 miles long

- Upper and lower parts of the coulee formed differently due to position of the Coulee Monocline.

* A flood-expansion bar (debris fan) developed at the mouth of the upper coulee as floods expanded into the Hartline Basin.

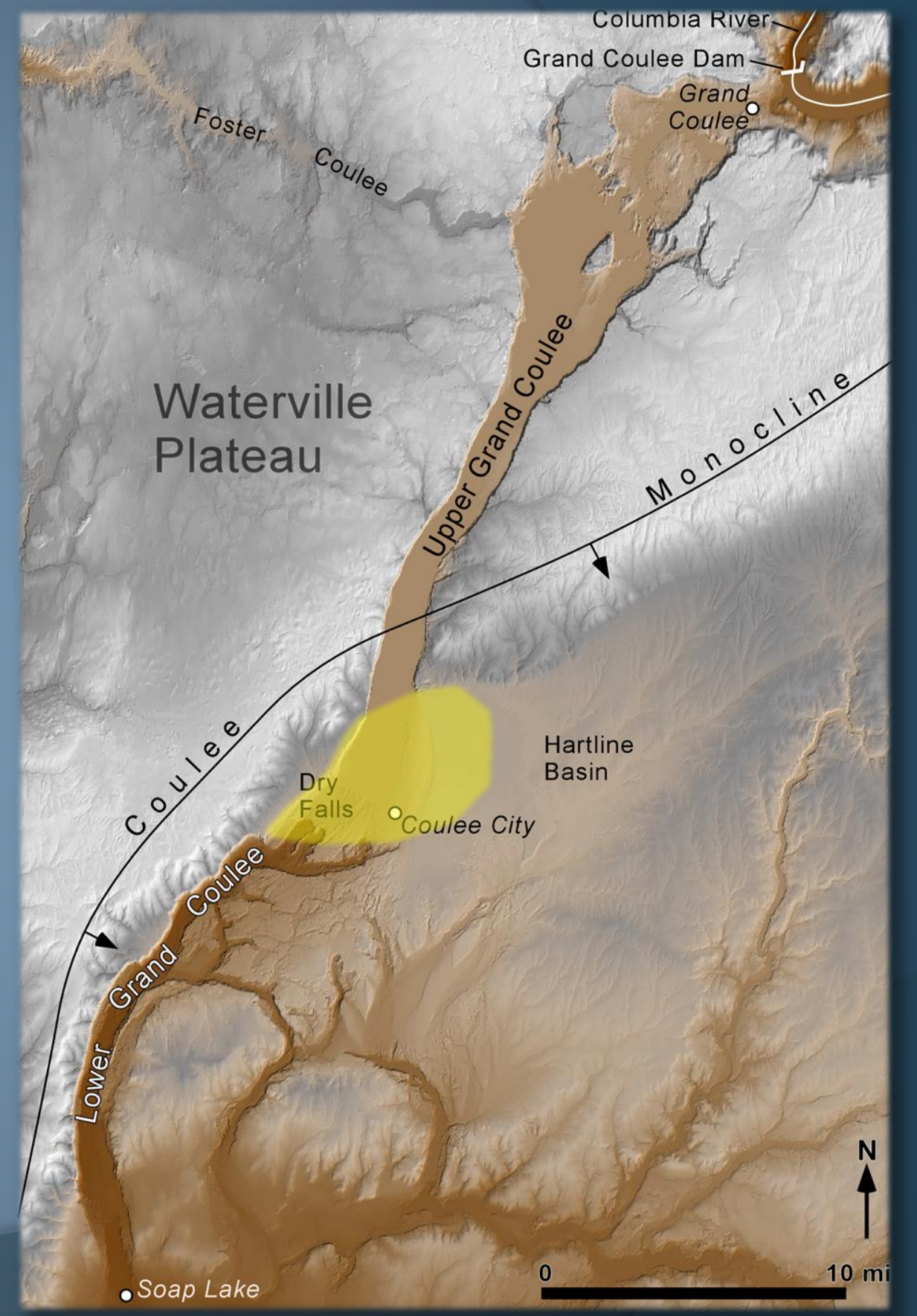




\section{Grand Coulee During Late-Glacial, Post- Missoula Floods' Time}

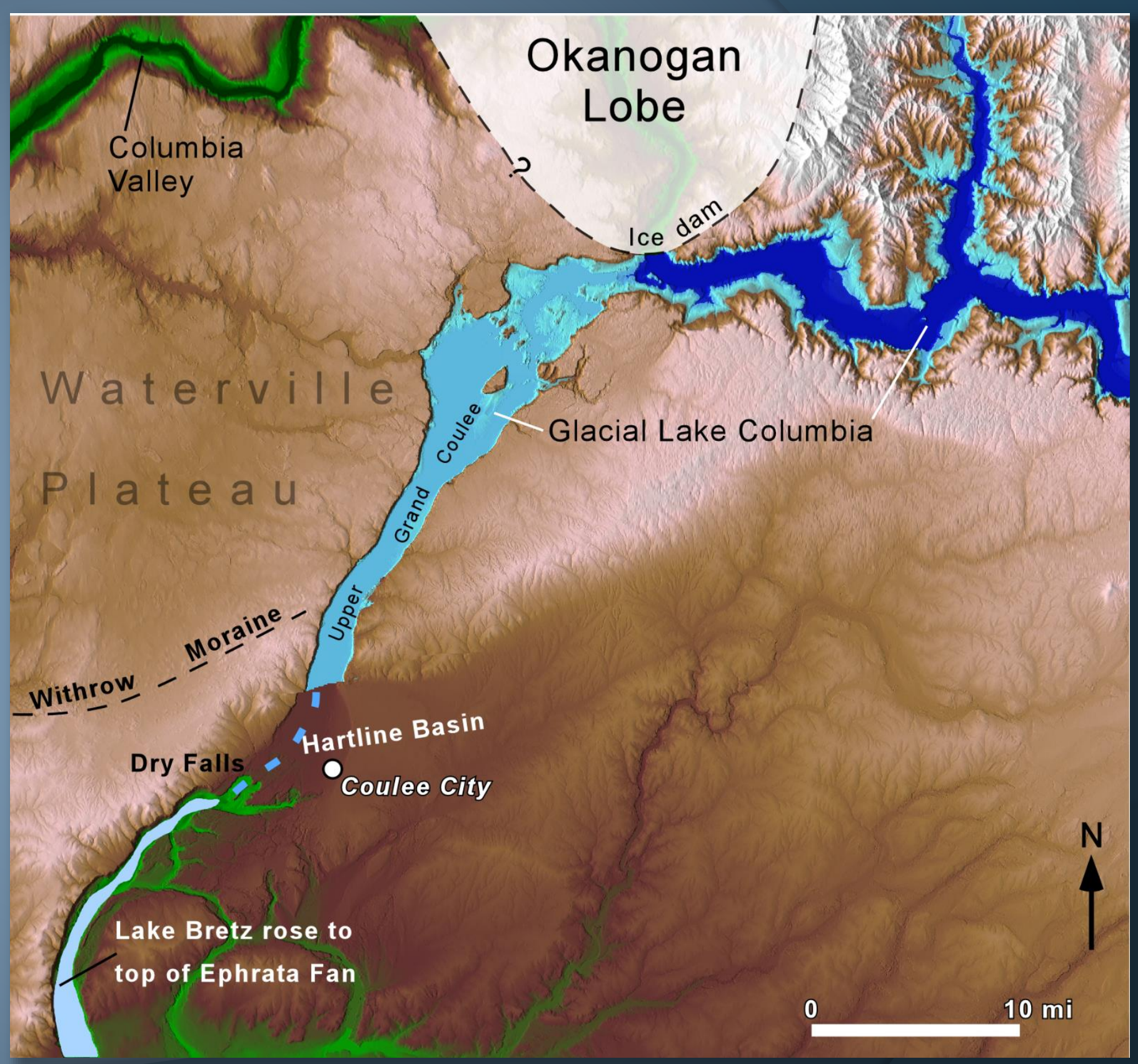

- Columbia River blocked by the Okanogan Lobe

( ) Meltwater diverted down Grand Coulee via ancestral Columbia River 
Evidence for Glacial Lake Columbia in Upper Grand Coulee

Varved Lake Deposits (to 1,620')

Delta Bars (to 1,680') 


\section{Varved Lake Deposits in Upper Coulee}

(- Lacustrine silt covers the floor of upper Grand Coulee

- Up to several hundred varves counted above last Missoula flood deposits

Conclusion: Glacial Lake Columbia in the upper Grand Coulee outlasted the Lake Missoula floods by several hundred years.

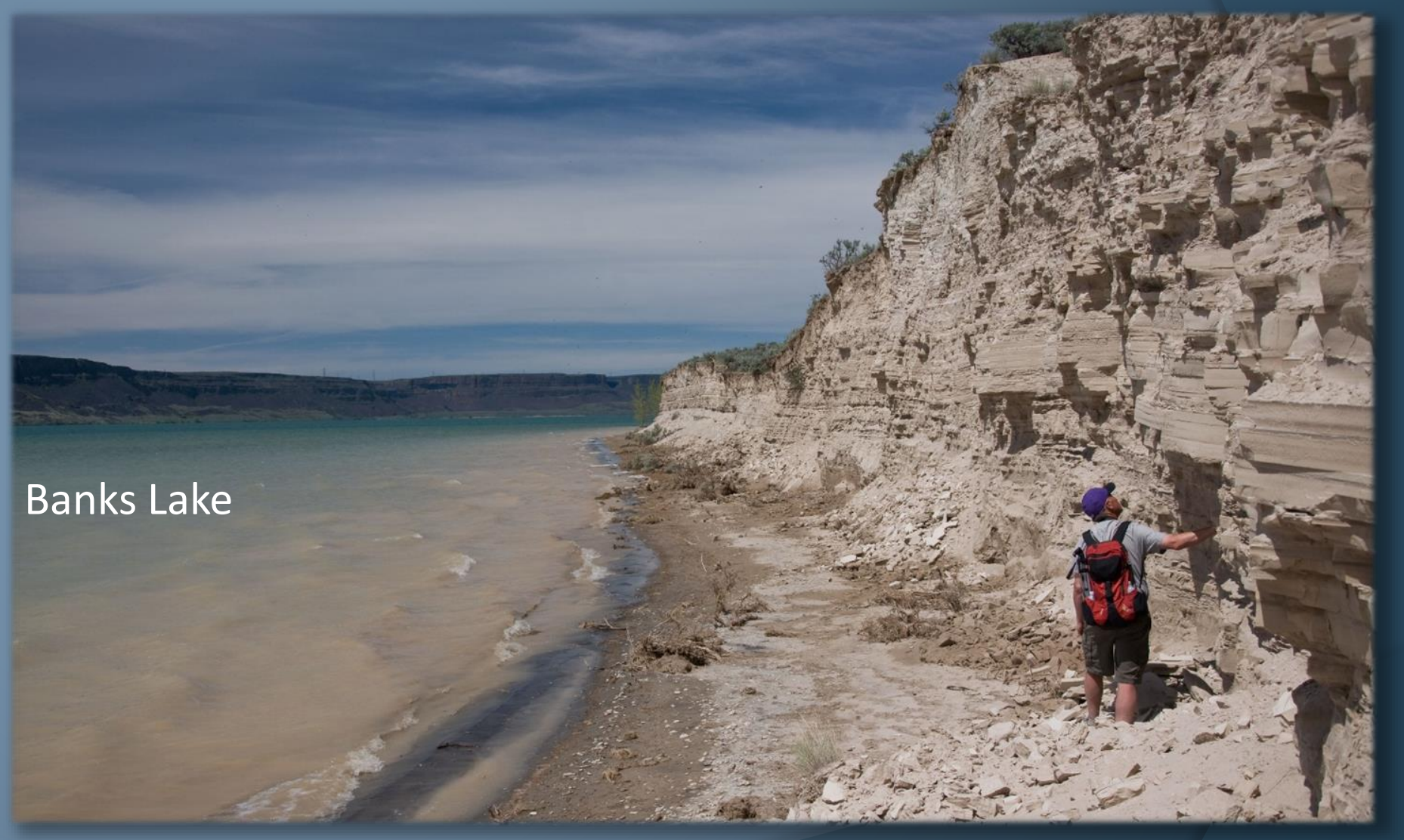




\section{Delta Bars in Upper Coulee}

○ Deposited where glacialmeltwater streams drained into Lake Columbia from the west off Waterville Plateau.
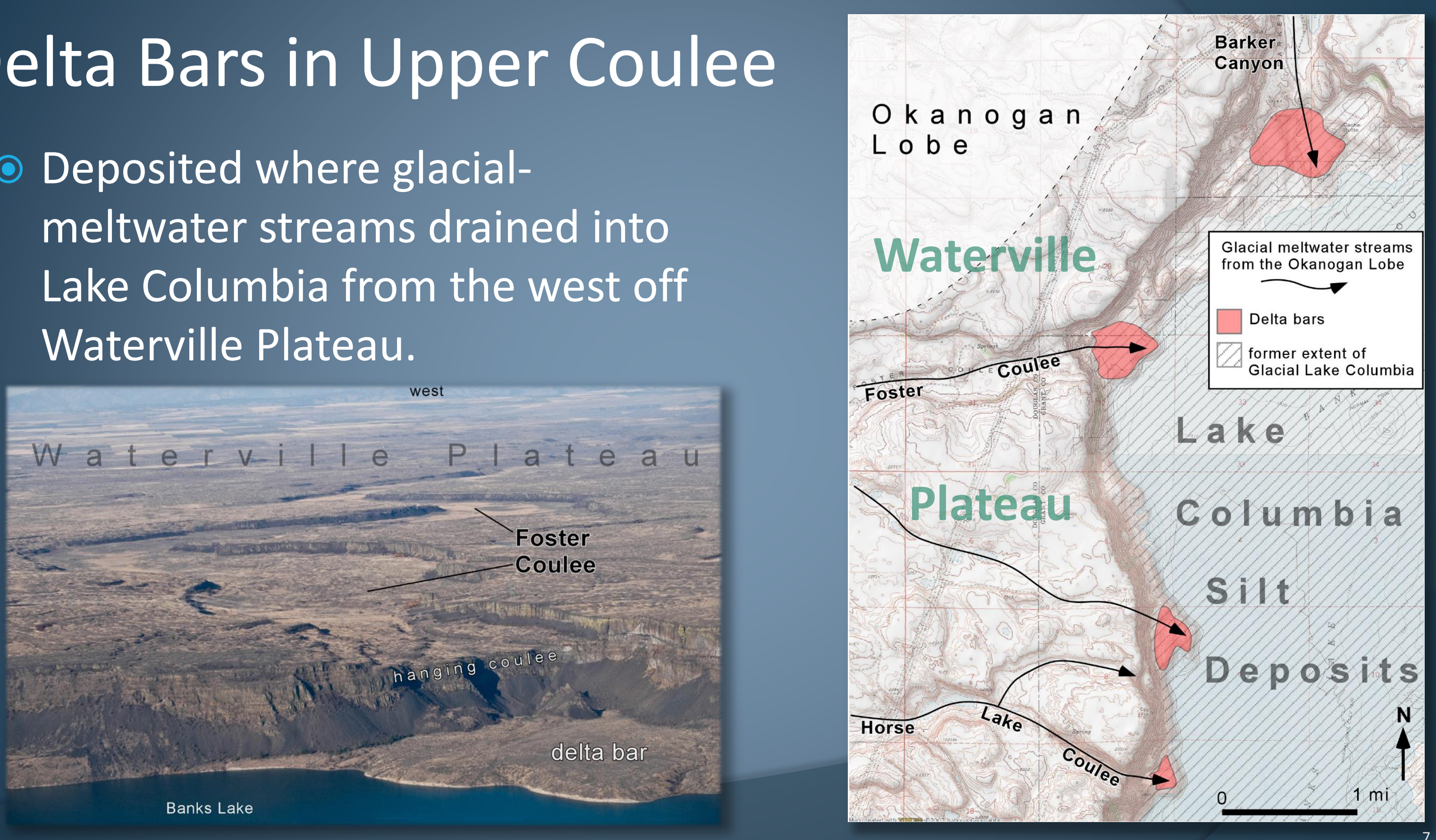
How could there be a Lake Columbia in the upper coulee when the only outlet for the lake was $>100 \mathrm{ft}$ below the level of lake deposits?

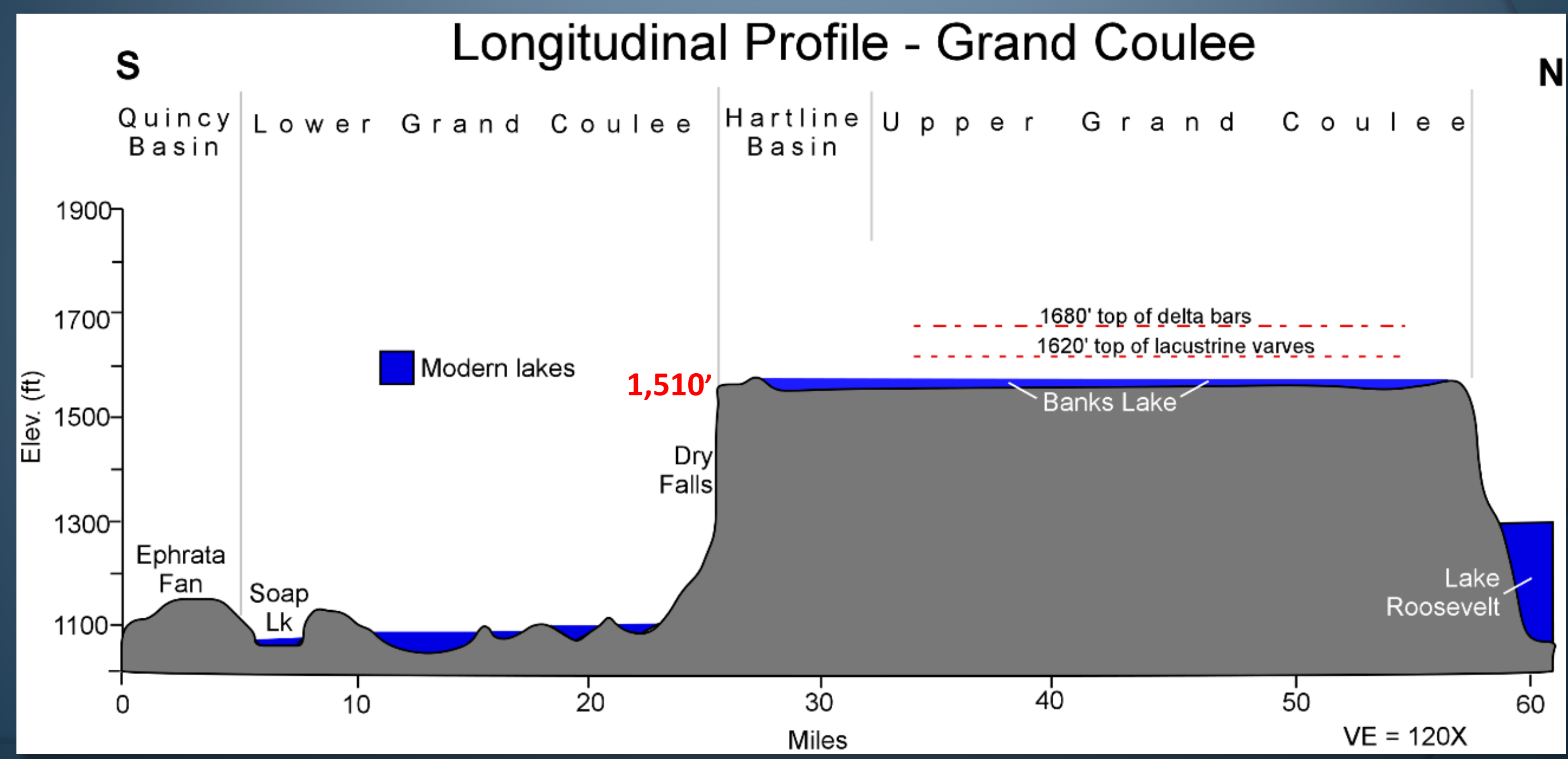




\section{Previous Interpretation}

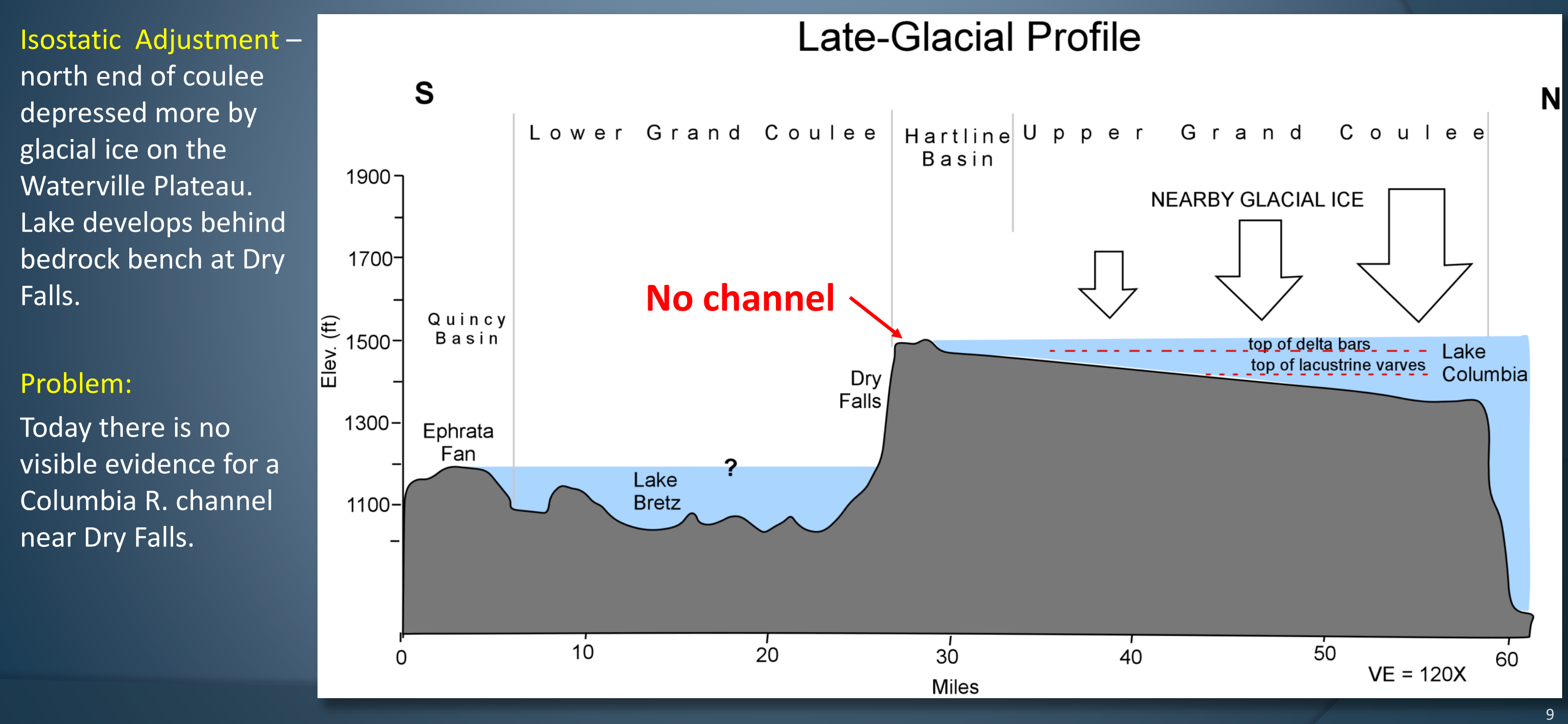




\section{No Evidence Exists for a Columbia River Channel in the Vicinity of Dry Falls}

○ Did a final erosional event occur at the end of the Ice Age to erase all evidence for a long-lived Columbia River in Grand Coulee?

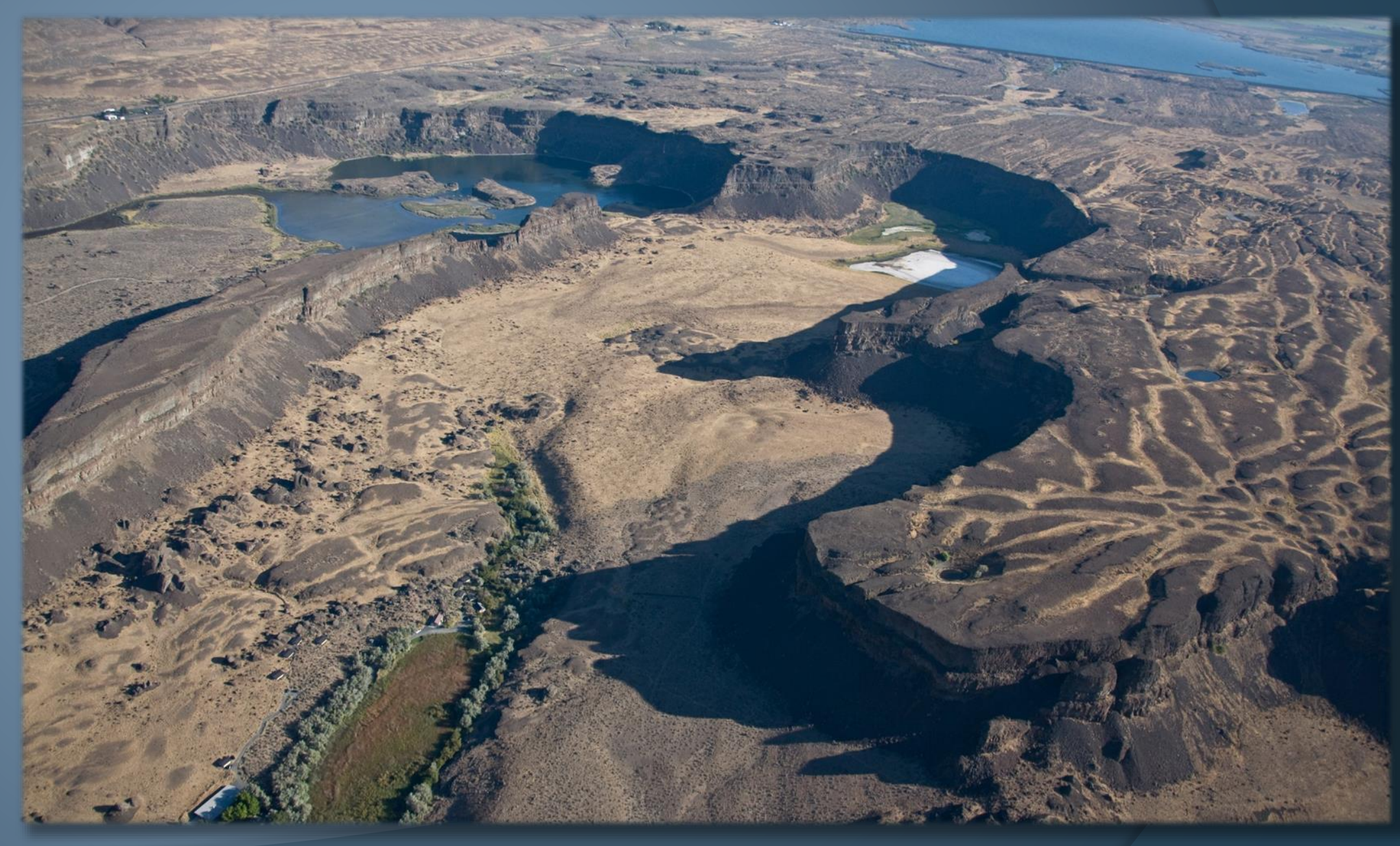


- A huge fan, the Coulee City Expansion Bar, lies at the mouth of the upper Grand Coulee, similar to Ephrata Fan at the mouth of the lower Grand Coulee.

- The center of the fan is eroded down to bedrock, but remnants of the bar are present along the coulee margins.

- At one time the bar may have completely blocked the upper coulee to hold back Glacial Lake Columbia.

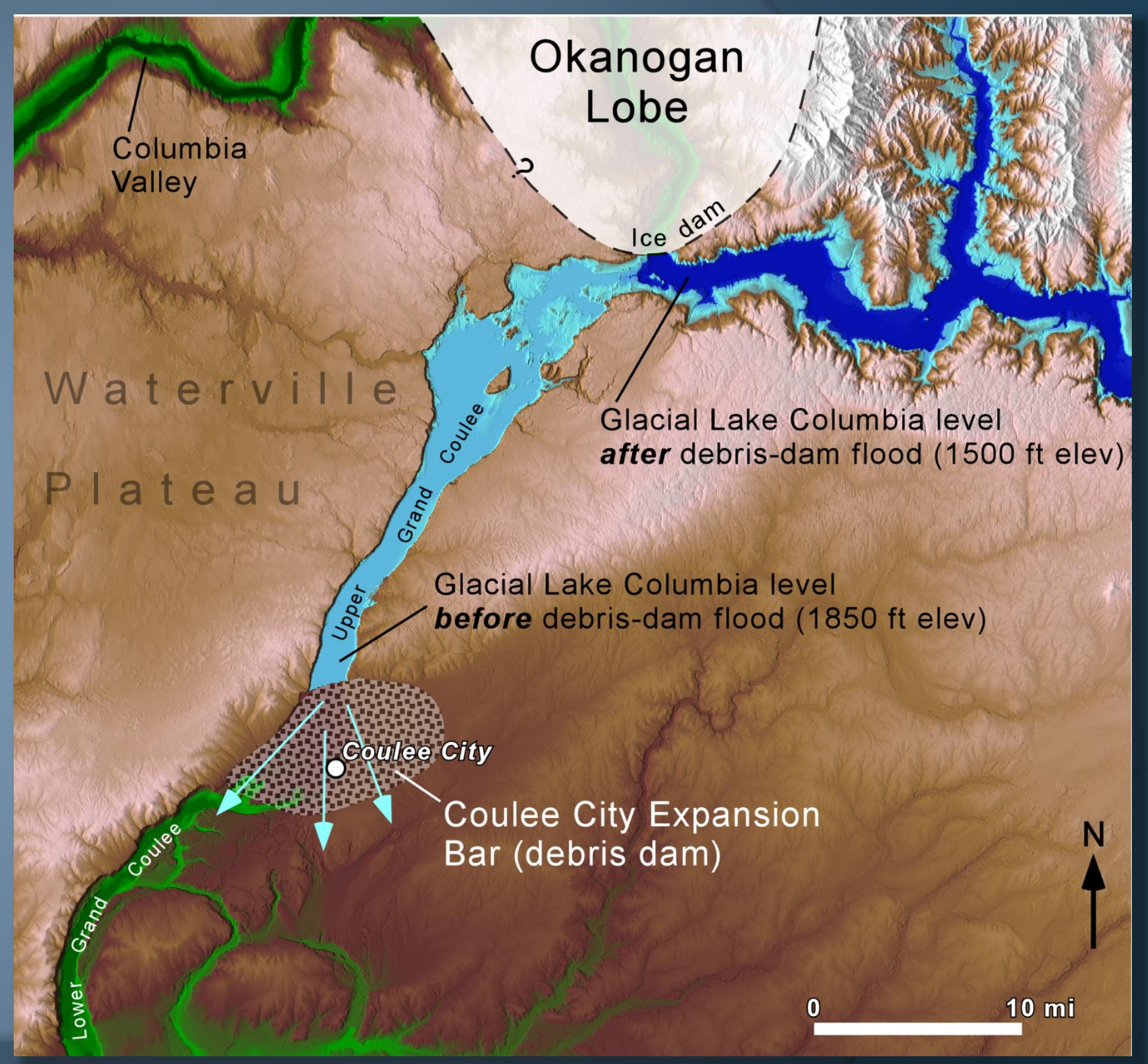




\section{Eroded Remnants of Coulee City Expansion Bar}

The top of the bar rises to near the same elevation on both sides of the Hartline Basin, suggesting a continuous features across the mouth of the upper coulee.

West Side

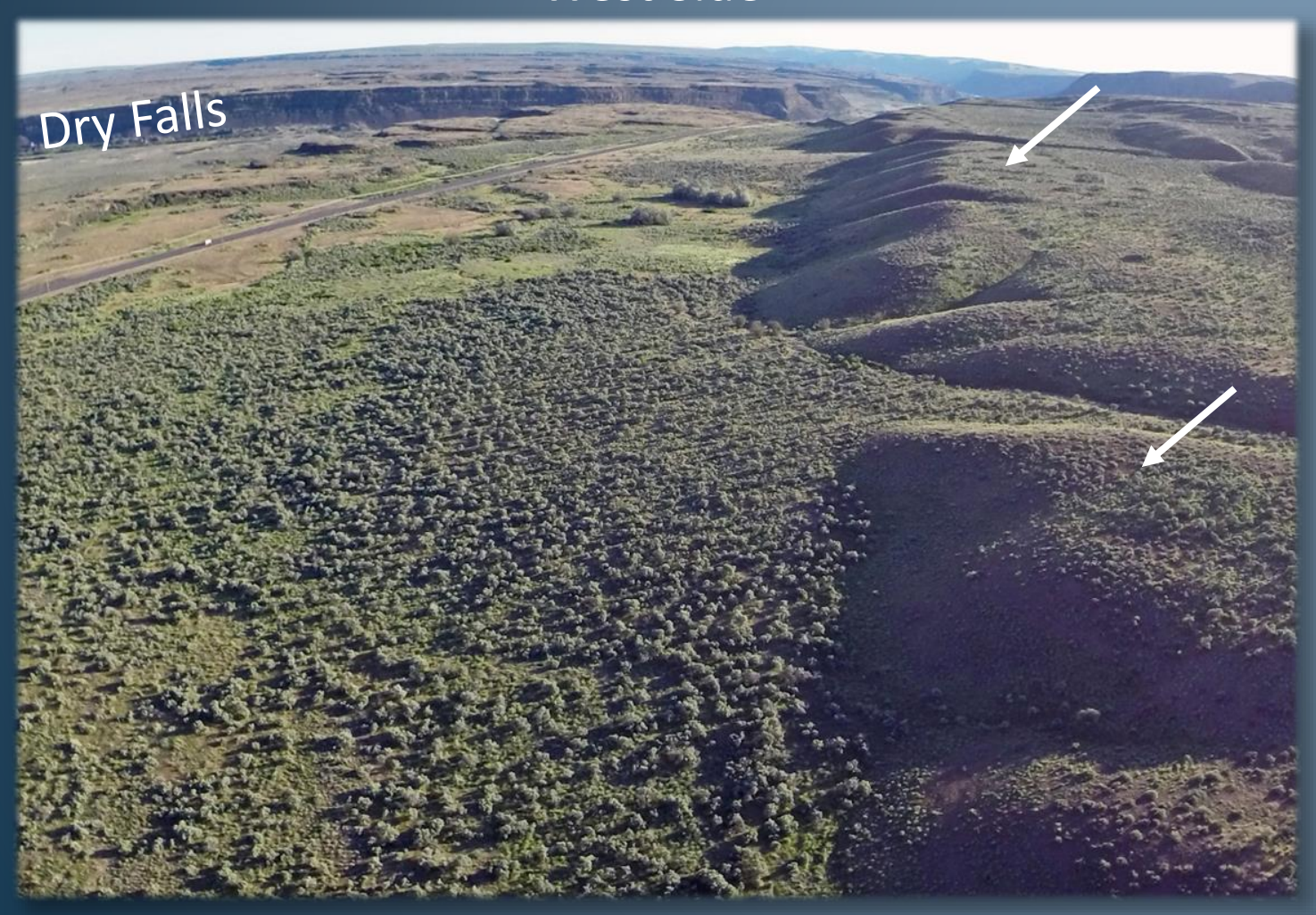

East Side

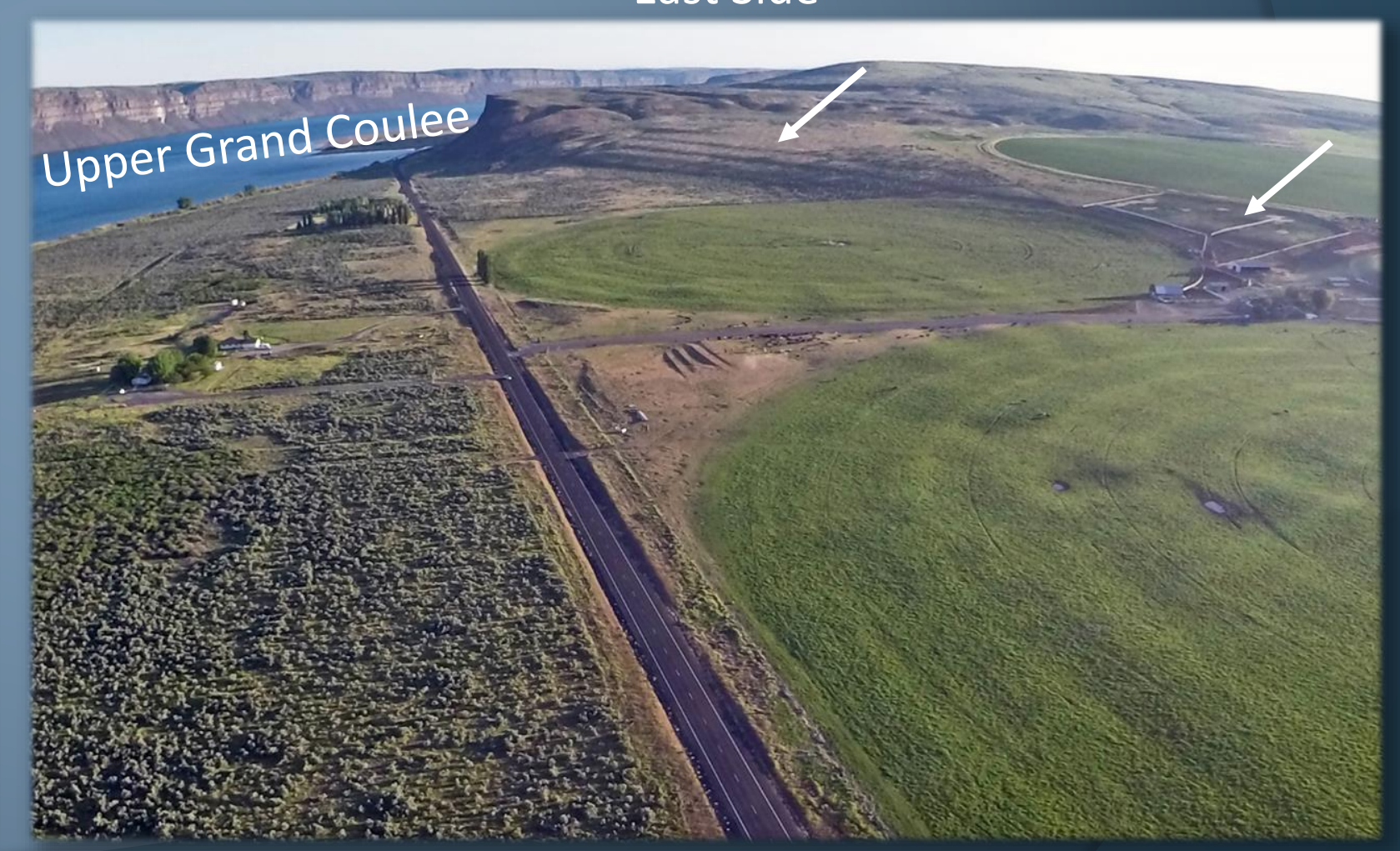




\section{Flood Gravel of Coulee City Expansion Bar exposed in US 2 roadcut (west side of bar)}

() Coarse, angular, and poorly sorted basaltic gravel and sand.

( ) Breaks with weak graded bedding suggest multiple Wisconsinan Missoula floods.

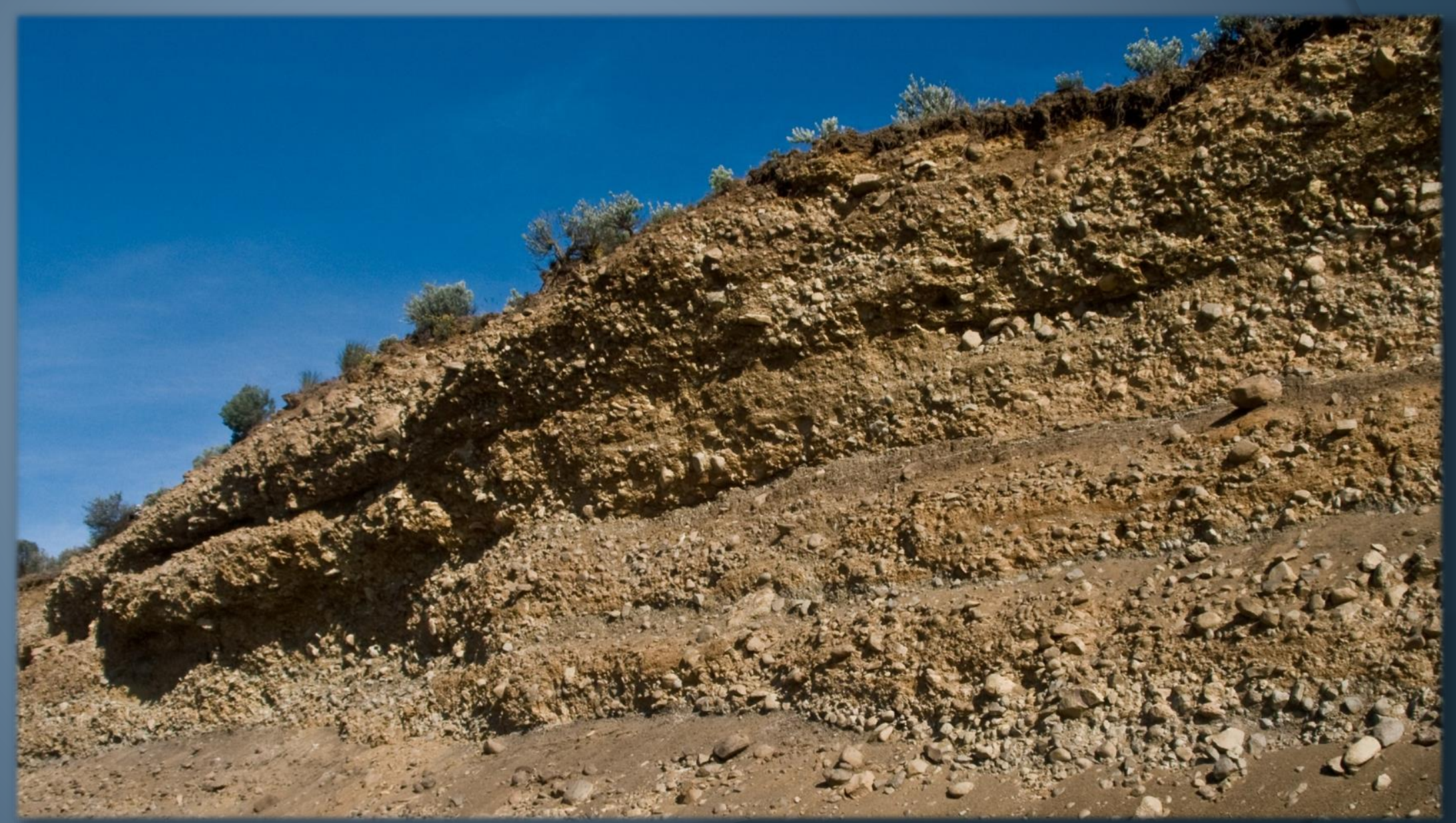




\section{Coulee City Expansion Bar}

( ) Located at the mouth of the upper Grand Coulee $300 \mathrm{ft}$ above the coulee floor

( ) Central part is missing - eroded away via breaching by Lake Columbia flood?
S

Quincy Lower Grand
Basin

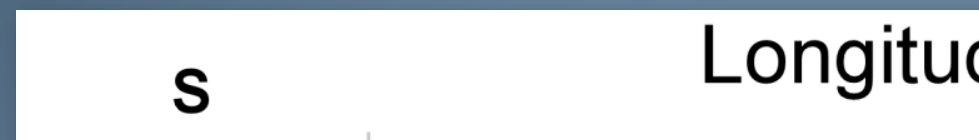

$$
\text { 迎 }
$$

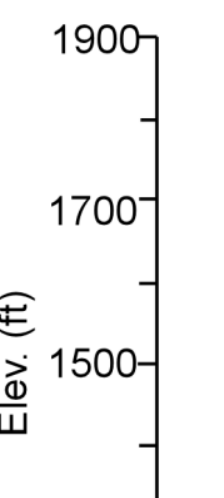

1300

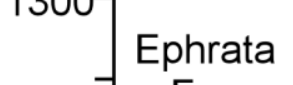

1100 Ephrata Fan

1100 0
Coule e Hartline U p p e $r$
Basin

G $r$ a $n$ d

Co u l e e

Coulee City

Expansion Bar

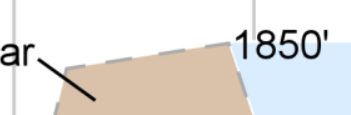

Lake Columbia

1680 ' top of delta bars

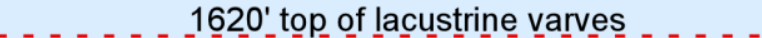

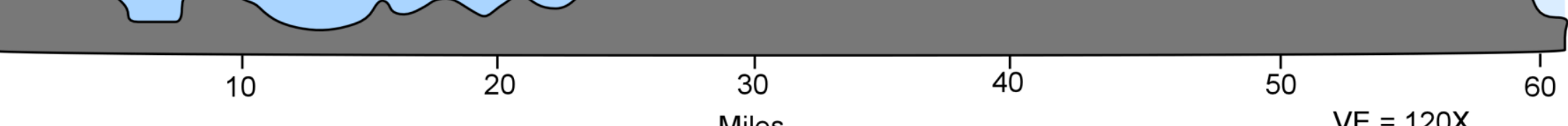

( ) Explains the lack of a Columbia River channel above or behind Dry Falls.

( ) Until the bar was breached, the floor of the coulee was protected from incision by the ancient Columbia R. 


\section{Possible Causes for Sudden Breaching of the}

Expansion Bar?

( ) Accelerated glacial melting and overtopping of the debris dam at very end of Ice Age.

( Hydraulic piping

( ) Seismicity leading to liquefaction and/or seiche wave impacting the debris dam

○ Others? 